\title{
ディープラーニングを用いた 高速道路の路面劣化予測モデル
}

\author{
橋本 申 1 -吉井 稔雄 2 -坪田 隆宏 3 - 全 邦釘 4 \\ 1非会員 株式会社 地域未来研究所（† 530-0003 大阪市北区堂島1-5-17 堂島グランドビル2階） \\ E-mail: hashimoto@refrec.jp \\ 2正会員 愛媛大学大学院教授 理工学研究科（干790-8577 愛媛県松山市文京町3） \\ E-mail: yoshii@cee.ehime-u.ac.jp \\ 3 正会員 愛媛大学大学院講師 理工学研究科（†790-8577 愛媛県松山市文京町3） \\ E-mail: t.tsubota@cee.ehime-u.ac.jp \\ 4正会員 東京大学大学院特任准教授 工学系研究科（干113-8654 東京都文京区本郷7丁目3番1号） \\ E-mail:chun@i-con.t.u-tokyo.ac.jp
}

\begin{abstract}
道路舗装は車両の快適・安全な走行を担うなど，道路交通を支える重要な基盤であり，将来の劣化進行 度を把握し効率的に補修することが求められる．路面性状測定データを利用して路面劣化予測を試みる取 り組みは数多くなされているが，ディープラーニングを用いた予測モデルは十分な検討はなされていない. そこで本研究では，ディープラーニングを用いて路面劣化予測モデルを構築し，RMSEを用いて重回帰モ デルとの比較を行うことで，予測再現性を定量的に評価した。 その結果, ディープラーニングによって従 来より高い再現性を持つモデルを構築することができる可能性が示された. また, 本研究で構築したモデ ルは空間移転性を有していなかったが，その一因として過学習が起きていることが確認された。
\end{abstract}

Key Words : pavement, rut depth, neural network, deep learning

\section{1. はじめに}

日本の公共インフラは，1960年代の高度経済成長期に 整備されたものなど，その老朽化が深刻な問題となって いる。しかし一方で，国家予算に占めるインフラ事業費 は減少傾向にあり，適切な維持管理が求められている.

こうした状況にあるインフラの中でも，特に道路舗装 への適切な維持管理が喫緊の課題とされる. 寸なわち, 道路舗装は, 雨天時の道路の泥濘化や乾燥時の砂塵を防 止することで車両の走行快適性を維持し環境を保全する ことや，路面の平坦性や透水性を維持し適度な滑り抵抗 性を持たせることで車両通行時の安全性を確保すること, また適切な構造や舗装材料を用いることて騒音・振動を 減らしつつ良好な道路景観を創出することなど，社会に おいて重要な役割を担っている，その一方で，道路舗装 は常に車両による活荷重を受けていることから, 他のイ ンフラ構造物等と比べて寿命が 10 年〜 20 年と短く, 継続 的かつ高頻度の保守点検を要する，さらに，近年では車 両の大型化や交通需要の増加に伴って，建設当初の想定 よりも早く劣化が進行してきていることから, 補修を要
寸る地点や将来の劣化進行を把握した上で, より効率的 に補修を行うことが求められる.

これまで, 舗装路面の劣化速度・劣化予測に関する研 究は, 複数時点で行われた路面性状調査の值を比較した 上で，外れ值と考えられるデータを除外する手法がしば しば取られてきた。しかしこの手法には，例えば調查手 法・機器・基淮の変化等によって生じる真の変動量とは 異なる測定誤差が結果に大きく影響を与え，かつ特定の 值を除外して分析に用いているといった問題が存在する.

また，近年情報科学の急速な発展により，ディープラ ーニングを用いた研究が分野を問わず広く行われつつあ る. 路面劣化予測においても, 機械学習やニューラルネ ットワークを用いた研究がか礼てより行われているが, ディープラーニングを用いた手法はまだ十分な評価がな されていない.

そこで本研究では, 劣化変動の起点を道路路面補修時 点とすることで，複数時点での調査結果を用いることに よる測定手法等の変化による影響を最小化した上で，路 面劣化予測モデルを構築する. また，ディープラーニン グによるモデルと従来手法によるモデルの予測再現性を 
定量的に比較することで，ディープラーニング手法の有 用性を評価する.

\section{2. はじめに}

\section{(1) 主な先行研究}

路面性状測定車が登場して以降，大量の路面性状デー 夕を得ることができるようになり，それを利用して将来 の路面性状を予測する試みが数多くなされてきた.

阿部・飯野1は，わだち掘れ量と道路の共用年数関係 について, 測定機器の開発技術的問題から生ずる真值と の「開発時に許された測定誤差」, 測定機器の距離計・ 地図上の距離・実際の距離等の差から生ずる「距離のず れに伴う誤差」, 測定機器の違いから生ずる「測定装置 間の誤差」の3種の誤差を考慮した上で，統計的に分析 を行い，測定データにはいくらか誤差が含まれるものの 定量的解析に十分耐えうるものであると結論づけた。 し かし，同一地点のわだち掘れの変化量に傾向が見られな いことや, 変化量より測定誤差の方が大きいと考えられ ることから，わだち掘れ量を毎年測定してもそのデータ から経年変化を得ることはできないと指摘した.

重原ら2は，ニューラルネットワークによるわだち掘 れ予測モデルを開発した. シグモイド関数を活性化関数 とした3層（隠れ層数1）全結合順伝播型で，IC区間・構 造物種別・車線種別・舗装種別・累積大型車交通量を説 明変数として，わだち掘れ量を予測するネットワークを 構築し, 北陸地方の高速道路データを用いて 10,000 エポ ック学習したところ，予測值と実測值が十分一致したモ デルを開発することができたとした，その予測から，盛 土と切土でわだち掘れ量に差はないことと, 密粒度アス ファルト舗装よりもポーラスアスファルト舗装の方がわ だち掘れが早く進行することを示した.

奥田ら（2016） 3)は，ディープラーニングによってわ だち掘れ量・ひび割れ率・平坦性を予測するモデルを開 発した. ユニット数 100 の隠れ層10層を含む 12 層全結合 順伝播型で，舗装種別・大型車交通量・路床支持力・最 新補修工法・供用期間 $・$ 調查年度 - 構造物種別 - 交差点 有無・道路幅員・前回調査值を説明変数として, わだち 掘れ量・ひび割れ率・平坦性のいずれかを予測するネッ トワークを構築した. その結果として，学習に用いたデ ータとは異なるデータに対して予測モデルを適用し，予 測值と実測值の平均二乗誤差と相関係数で評価し，また 予測值と実測值の散布図から值の大きい区間ほど過小評 価する傾向があることを示した.

奥田ら（2017）44は，リカレントニューラルネットワ ークモデルを用いて, より現実的な精度評価を行うため の新たな学習手法を提案した上で, 時刻情報を含む路面 性状データから予測モデルを構築した，従来，時刻情報
を持つデータから予測モデルを構築する場合は全ての時 刻のデータをパラメータ推定に用いていたが，実運用に 際しては観測不能な将来の予測を行う必要があることか ら，データをある時点で分割して早い方のデータのみを パラメータ推定に用いる手法を提案した，その上で，従 来手法と提案手法それぞれのモデルの予測性能を比較し， 従来手法では予測性能が過大評価され，提案手法ではよ り現実的なモデルの評価が可能なことを示した.

大窪ら゙は，空間統計学の手法を用いて抽出した劣化 速度の速い区間に対して，一般化線形混合モデルを用い て劣化速度に影響を与える要因を分析した．四国地方の 高速道路を対象として，まず，ひび割れ率・わだち掘れ 量・IRIの変化速度に関してMoranのI統計量を計算し，空 間的自己相関が生じている，つまり劣化速度が速い区間 が隣接しているホットスポットおよび劣化速度が遅い区 間が隣接しているコールドスポットを抽出した.ひび割 れ率のホットスポットに対して, 一般化線形混合モデル によって交通量・降水量 - 凍結防止剂散布量 - 表層厚 ・ 基層厚・構造物種別・路線が劣化速度に与える影響を分 析した. その結果, 降水量が有意に劣化速度を速め, ま た構造物種別に関しては盛土・切土区間で劣化速度が有 意に速いという結論が得られた.

Gongらけは，過去25年間に記録された舗装路面性状デ ータを活用し，多層による順伝播型ディープラーニング モデルを構築し, 舗装路面のわだち掘れ量の予測を行つ た. 重回帰モデルに基づく従来手法》との予測精度の比 較を実施した結果，ディープラーニングによる予測精度 は重回帰モデルを大きく上回ることを確認している.

\section{(2) 先行研究の問題点}

同一地点におけるわだち掘れ量の值は，補修がない限 り年々上昇するはずであるが，調査データにはそれに反 する值が記録されていることがある. 従来の研究では, しばしばこのような例をデータの䛊りとして除外する方 法がとられてきた。例えば重原らはわだち掘れ量が「極 端に減少している」データを除外しており, 奥田ら

(2017） $\left.{ }^{4}\right)$ は複数時点間における調查值の変化量分布の 上下5パーセンタイルを外れ值として除外している. 大 窪らは，複数時点間における変化量を目的変数にしてお り, 補修が行われていないもかかわらず路面性状が改善 している区間は全て除外している. このような，值の変 化量から一部の区間のみを人為的に除外する手法は，一 定の合理性は認められるものの, 路面性状が改善した場 合のデータを除外するなど，特定方向の測定誤差を含む データのみを棄却していることとなり，単年で見た場合 の測定值の分布が偏るなどの問題点が想定される.

Gongらのの研究においては, 25年間のデータを活用して いるが，その間の調查手法の変化による影響については 
記述が為されていない.

また，将来の補修計画策定に向けた予測モデルを構築 寸る際には，その予測精度の評価が不可欠である。 しか しながら従来の研究では，その評価が十分に行われてい ないことがある. 例えば重原ら2の研究では，モデルの 実測值と予測值が「よく一致した」としているのみで, 定量的な評価は行われていない，また，全てのデータか らパラメータの推定を行い，同じデータを用いてモデル の評価を行っているため，分析対象路線全体のおおまか な傾向は予測できても，短い特定1区間や学習していな い別路線の予測には不向きである可能性がある. 奥田ら (2016）ㅊは，パラメータの推定に用いたのとは別のデ 一タに対して，モデルによる予測值との平均二乗誤差と 相関係数を算出することによって，予測性能の定量的な 評価を下している.しかしその值を一見しただけでは, そのモデルがどの程度優れているのか判断し難い．

\section{(3) 本研究の位置づけ}

先行研究には, データの処理方法とモデルの評価方法 という2つの問題があることを指摘した.

本研究では, 最新の路面性状調查值のみをデータとし て利用し, 前回調査ではなく補修時点を劣化変動の起点 として扱うことによって, 複数時点の調査值を用いるこ とによる測定手法等の変化による影響を極力排除する.

また，值の上下を元にした外れ值除去処理は，特定方向 の誤差を持ったデータの染意的な除去につながる可能性 があるため, 行わない. 予測モデルの評価には, パラメ 一タ推定に用いたものとは別のデータに対する平均二乗 誤差と相関係数を算出し，かつ従来手法による予測モデ ルと比較することで，その再現性を定量的・定性的に評 価する.

\section{3. 研究概要}

\section{(1) 研究指針}

本研究では，供用期間を主要因として将来の路面性状 值を予測する路面劣化予測モデルを, ディープラーニン グを用いて構築する.さらに, 構築したディープラーニ ング手法の有用性を検証するために, 従来手法による予 測モデルを代表して重回帰モデルとの再現性比較を行う。

\section{(2) 用いる変数}

本研究では, 各路線の各0.1kpを1区間として分析を行 い, 路面劣化に影響を与えそうな複数の要因から，当該 区間の将来の路面性状值を予測するモデルを構築し，そ の再現性を検証する. 用いる変数は表-1の通りである.
表-1 変数一覧

\begin{tabular}{|c|c|}
\hline 説明変数 & 前処理 \\
\hline 供用期間 & \multirow{9}{*}{ 正規化 } \\
\hline 交通量 & \\
\hline 大型車交通量 & \\
\hline 曲率半径 & \\
\hline 縦断勾配 & \\
\hline 路面第1層の厚み & \\
\hline 路面第2層の厚み & \\
\hline 降水量 & \\
\hline 凍結防止剤散布量 & \\
\hline 車線種別 & \multirow{3}{*}{$\begin{array}{l}\text { ダミー } \\
\text { 変数化 }\end{array}$} \\
\hline 構造物種別 & \\
\hline 舖装種別 & \\
\hline
\end{tabular}

\section{（3）予測再現性の評価方法}

今回構築するモデルは, 将来の路面性状值の予測を目 的とする. よってモデルには，学習に用いた既知のデー タへの再現性に加えて, 学習していない未知のデータに 対する高い再現性を有することが求められる，そこで本 研究では，K-分割交差検証手法を用いて，モデルの予測 性能を測る. 本研究では, 分割方法にランダムに分割す る方法と，人為的に分割する方法とを用いて検証を行う. 前者による検証では，全データを完全にランダムにK 等分してサブセット群を作成する（以下，“ランダム分 割検証”）。ただし，例えば，隣接区間の一方を学習用 データ，もう一方を検証用データとした場合，両区間の データ值が類似したものとなる可能性がある為, ランダ ム分割検証ではモデルの他路線への適用性については, その確認が困難である，そこでモデルの空間移転性を検 証寸るために, 本研究で扱うデータが4つの路線から構 成されることを利用して，後者の人為的に分割する検証 では，各路線が1つのサブセットとなるようにデータを 4 分割して検証を行う（以下，“路線別分割検証”）。

本研究では，分析対象区間に対して最適化された路面 劣化予測モデルを構築する為, ディープラーニングモデ ルの構築に際してはランダム分割検証によってパラメー 夕を決定する. その後, 構築したモデルの精度や特性を 従来手法と比較する際には路線別分割検証も併せて実施 することにより，空間移転性を含めた評価を実施する.

モデルの再現性評価に際しては, 予測值と実測值の平 均二乗誤差（以下，“RMSE”）を用いることで，予測 再現性を定量的に評価する.

\section{4. 分析データ概要}

(1) 分析対象区間

分析対象区間は，四国の高速道路ネットワークを構成 
する高松自動車道・松山自動車道・高知自動車道 $・$ 徳島 自動車道の4路線のうち, 西日本高速道路株式会社が管 理する区間の上下線全路線である。

\section{(2) 分析データ}

本研究では, 以下に示寸路面性状データ, 道路構造デ 一夕, 感知器データ, ならびに路面環境データを用いる.

\section{a) 路面性状データ}

路面性状データからは，各車線の0.1kp（100m）区間 ごとのわだち掘れ量と，その計測を行った日付，その区 間で今まで行われた補修の日付の情報が得られる. 2012 年度から2016年度までの5年分のデータがあり, 路面性 状調査は 1 年に1度行われているが，全区間が毎年調査さ れているわけではなく, 路線ごとに 3 年に1度の頻度で調 查が行われている. なお，1区間内でもわだちの深さは 場所によって異なるため，区間内で複数回測定されたう ちの最大值を当該区間のわだち掘れ量と定義している.

データでは, 複数時点間に補修が行われていないにも かかわらず, 路面性状が改善されている区間が存在する. 例として, 高松自動車道の坂出JCT〜善通寺IC間では, 2012年度と2015年度にそれぞれ路面性状調查が行われた が，その間に補修が行われなかった241区間のうち233区 間でわだち掘れ量が減少しており，2012年度調查と2015 年度調查の間で，測定方法・基準等が異なっていたこと が推測される. このように測定方法の差に起因すると考 えられる誤差による影響を最小限にするため, 本研究で は，測定方法が同一と考えられる期間のデータのみを使 用する. 寸なわち, データの最新年である2016年時点で, 各路線において最後に行われた最新の調查の值のみを用 いる.

また，本研究では路面性状に影響を与える要因の1つ として，供用期間を用いる. 路面性状が調査された日と その直前に路面補修がなされた日の間の日数を計算し, 当該区間の供用期間とする。ただし，補修が1度も行わ れていない区間に関しては, 開通日から調査日までの日 数を供用期間とする.また，月のみで日付けが記録され ていない補修日・調査日については，各月1日に行われ たものとして扱うこととする.

b) 道路構造データ

道路構造データからは，各車線の0.1 kp（100m）区間 ごとの曲率半径・縦断勾配・第1層の厚み・第2層の厚 み・車線種別・構造物種別・舗装種別の情報が得られる. 構造物種別は, 盛土・切土・橋梁・トンネルの4種類 から構成されている. 舗装種別は, 密粒舗装・高機能舗 装・コンクリート舗装の3種類から構成されている。 な お，車線種別には，一般走行車線・追越車線の2種類だ けでなく, 登坂車線・付加車線・ゆずり車線等が存在す るが，これら総延長に占める割合は $1 \%$ 未満と少なく,
分析への影響も限定的であると考えられるため，いずれ も一般走行車線として取り扱う。

\section{c) 感知器データ}

感知器データからは, 各IC・JCT間の1時間単位の交通 量・大型車交通量の情報が得られる. 本研究では, 2012 年1月1日0時から2016年12月31日23時までの5年間のデー タを用いて分析を行う．以下では，時間帯別に各区間の 5 年間の交通量および大型車交通量を集計し，それぞれ を日数で除し，1日あたりの時間帯別平均通行台数を算 出して, 当該区間の交通量および同大型車交通量とする. ただし，データには，1時間あたりの交通量が0台あるい は未記載の時間帯が含まれるが，これらは機器の不具合 によるものと考えられるため，0台あるいは未記載とな っている時間帯とその前後 1 時間が含まれる日は一日平 均通行台数の計算から除外した.

\section{d) 路面環境データ}

路面環境データとして，前期供用期間における各区間 ごとの累積降水量と凍結防止剂散布量（使用塩重量）の 情報を用いる. 累積降水量は, 供用期間の月数で除して 1ケ月平均降水量を算出し, 当該区間の降水量とする. なお，トンネル区間では路面が降雨にさらされることは ないが，構造物種別でトンネル区間であることが説明さ れるため, 值の補正は行わなかった。

\section{(3) 分析用データベース}

予測モデルを作成するにあたって，上記の4つのデー タを1つに統合し分析用データベースを作成した。

感知器データを除いて, 全て各車線の $0.1 \mathrm{kp}(100 \mathrm{~m})$ 区間ごとに集計されているため，本研究でも各車線の $0.1 \mathrm{kp}(100 \mathrm{~m})$ 区間ごとに集計・分析を行う. 感知器デ ータは，各IC・JCT間ごとに記録されているが，その間 はどの0.1kp区間でも交通量が同じであるとして取り扱 う。また，片側二車線以上の区間では，各車線の交通量 は等しいものとして, 等配分した值を各車線の交通量と する.

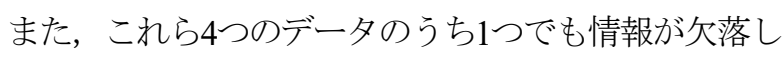
ている区間は分析対象から除外した．例として，道路幾 何構造データは2010年の情報に基づいており，2015年に 開通した徳島自動車道の徳島IC〜鳴門JCTの区間が含ま れていないことから，分析対象から除外した．除外後の データは全13,653区間から構成される.

\section{5. ネットワークの検討}

ディープラーニングよる予測モデルは，多層によって 構成される順伝搬型ネットワークを基本に構成する. あ る入力サンプル $\boldsymbol{x}_{n}$ について, 順伝搬の計算は式(1), (2)に のように表される8). 
表-2 変更パラメータ一覧

\begin{tabular}{|l|l|}
\hline パラメータ & 值 \\
\hline 隠れ層の数 & 4層, 10層 \\
\hline ユニット数 & $100,50,25,10,5$ \\
\hline 活性化関数 & ReLU関数, シグモイド関数 \\
\hline
\end{tabular}

表-3 隠れ層数 4層のユニット数パターン一覧

\begin{tabular}{|l|l|l|}
\hline \multirow{2}{*}{ パターン名 } & \multicolumn{2}{|l|}{ 各層のユニット数 } \\
\cline { 2 - 3 } & 1,2 層目 & 3,4 層目 \\
\hline$[100-100]$ & 100 & 100 \\
\hline$[100-50]$ & 100 & 50 \\
\hline$[100-20]$ & 100 & 20 \\
\hline$[100-10]$ & 100 & 10 \\
\hline$[100-5]$ & 100 & 5 \\
\hline$[50-50]$ & 50 & 50 \\
\hline$[50-20]$ & 50 & 20 \\
\hline$[50-10]$ & 50 & 10 \\
\hline$[50-5]$ & 50 & 5 \\
\hline$[20-20]$ & 20 & 20 \\
\hline$[20-10]$ & 20 & 10 \\
\hline$[20-5]$ & 20 & 5 \\
\hline$[10-10]$ & 10 & 10 \\
\hline$[10-5]$ & 10 & 5 \\
\hline$[5-5]$ & 5 & 5 \\
\hline
\end{tabular}

表-4 隠れ層数 10 層のユニット数パターン一覧

\begin{tabular}{|l|l|l|l|l|l|}
\hline \multirow{2}{*}{ パターン名 } & \multicolumn{4}{|c|}{ 各層のユニット数 } \\
\cline { 2 - 6 } & 1,2 & 3,4 & 5,6 & 7,8 & 9,10 \\
\hline$[100 \sim 100]$ & 100 & 100 & 100 & 100 & 100 \\
\hline$[100 \sim 5]$ & 100 & 50 & 25 & 10 & 5 \\
\hline
\end{tabular}

$$
\begin{gathered}
\boldsymbol{v}_{n}^{(l)}=\boldsymbol{W}^{(l)} \mathbf{z}_{n}^{(l-1)}+\boldsymbol{b}^{(l)} \quad(l \geq 2) \\
\boldsymbol{z}_{n}^{(l)}=\left\{\begin{array}{cl}
\boldsymbol{x}_{n} & (l=1) \\
\phi^{(l)}\left(\boldsymbol{v}_{n}^{(l)}\right) & (\text { otherwise })
\end{array}\right.
\end{gathered}
$$

ただし，

$\boldsymbol{v}_{n}^{(l)}$ : サンプル $\boldsymbol{x}_{n}$ を入力した場合の $l$ 番目の層への入力 ベクトル

$\mathbf{z}_{n}^{(l)}:$ サンプル $\boldsymbol{x}_{n}$ を入力した場合の $l$ 番目の層からの出 カベクトル

$\boldsymbol{W}^{(l)}: l-1$ 層とl層の間に線形変換における重み

$\boldsymbol{b}^{(l)}: l-1$ 層とl層の間に線形変換におけるバイアス

$\phi^{(l)}\left(\boldsymbol{v}_{n}^{(l)}\right): l$ 層における活性化関数

である。

同モデルでは，隠れ層の数，各層のユニット数，ある いは活性化関数の設定の違いによってその再現性が変化 寸る，そこで，本章では，これらのパラメータの適切な 組み合わせを求めるために, パラメータの組み合わせを 変更した多数のネットワークを適用して，それぞれに学

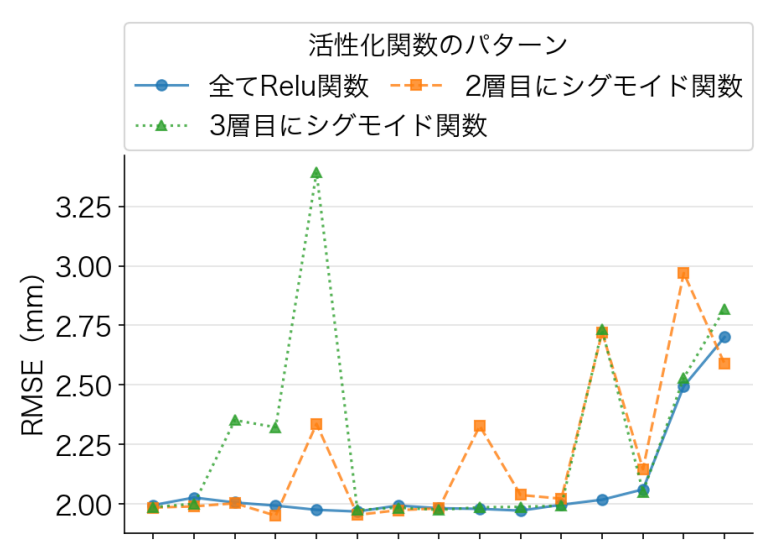

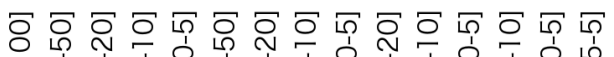

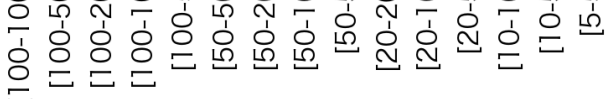
ユニニット数のパターン

[1, 2層目のユニット数 - 3,4層目のユニット数 $]$

図-1＼cjkstart隠れ層数 4層ネットワークの予測再現性比較

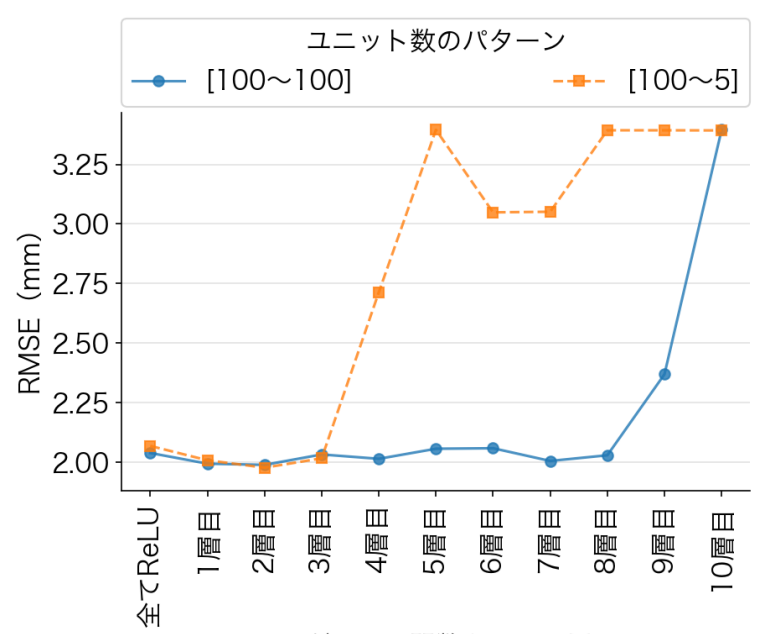

シグモイド関数を用いた層

図-2 隠れ層数 10 層ネットワークの予測再現性比較

習を行い，再現性の比較検討を行う.

(1) 検討するネットワークパターン

各パラメータに設定する值を表-2に示す，なお，エポ ック数は1,000, 最適化関数はAdam, 損失関数はRMSEと する. 以下，隠れ層の数の別に検討結果を報告する.

a) 隠れ層 4 層ネットワーク

隠れ層を4層に設定した場合には，ユニット数は，1， 2層目と3, 4層目が同数でかつ深い層ほど少なくなる組み 合わせとし，表-3に示す15パターンを用いる．活性化関 数は，全てReLU関数のものと，そこから隠れ層の 2 層目 或いは3層目のみをシグモイド関数に換えたものの3パタ ーン，すなわち，ユニット数15パターンメ活性化関数 3 パターンの計45種類のネットワークモデルについて学習 を行い，各モデルの再現精度を比較する. 


\section{b) 隠れ層 10 層ネットワーク}

隠れ層を10層に設定した場合には，表-4に示すように， 隠れ層全てのユニット数が100のパターンと, 深い層ほ どユニット数が少ないパターンの，2パターンを用いる. 活性化関数は, 全てReLU関数のものと, そこから10層 ある隠れ層のうちのいずれか 1 層をシグモイド関数に換 えたものの11パターンを用いる．したがって，隠れ層10 層ネットワークでは, ユニット数 2 パターンメ活性化関 数11パターンの, 合計22種類のネットワークモデルを学 習し，各モデルの再現精度を比較する.

\section{(2) 検討結果}

図-1，図-2には，ランダム分割検証による各モデルの 再現性検証結果を示寸.

隠れ層の数に関しては，4層と10層とでその再現性に 大きな差異は認められなかった. 一般にディープラーニ ングモデルでは層の数が多いほど精度が向上することが 期待されるが，今回使用したデータセットに対しては, 4層程度で十分な学習ができていることが推察される. 従って, 多数のパラメータを有する10層ネットワークよ りも, パラメータ数の少ない憎ネットワークの方が, より適した予測モデル構造といえる.

隠れ層のユニット数に関しては，4層ネットワークの 場合，一層目が20以下の構造では再現性が低下した。こ のことから，第一層のユニット数は 20 より多く設定する ことで高い精度を確保できると考えられる.

活性化関数にシグモイド関数を用いたネットワークの 場合に，予測值に全て同じ值を出力するモデルが存在し た.これは，学習時に勾配消失が起きたためと推察され る. 対して, ReLU関数はこれが発生しづらく, また単 純な構造のため計算も早いという利点が知られている.

したがって，本モデルにおいても，ReLU関数を用いた ネットワークを用いることとし，以下では隠れ層数が4 層, ユニット数が全て100, 活性化関数は全てReLU関数 のネットワークによる予測モデルをディープラーニング 手法によるモデル（以下，“DLモデル”）とし，重回 帰モデルとの比較を行う。

\section{DLモデルと重回帰モデルの比較}

\section{(1) 比較結果}

DLモデルと重回帰モデルの再現性比較結果を表-5に 示す.

ランダム分割検証においては，DLモデルが重回帰モ デルより優れた值を示しており，ディープラーニング手 法によるモデルを用いることで, 再現性が高くなる可能 性が示された.

一方，路線別分割検証においては，重回帰モデルが
表-5 モデル別RMSE (mm)

\begin{tabular}{|c|r|r|}
\hline \multirow{2}{*}{ モデル } & \multicolumn{2}{|c|}{ データ分割方法 } \\
\cline { 2 - 3 } & \multicolumn{1}{|c|}{ ランダム分割 } & \multicolumn{1}{|c|}{ 路線別分割 } \\
\hline 重回帰 & 2.69 & 4.07 \\
\hline DL & 1.99 & 5.45 \\
\hline
\end{tabular}

表-6 路線別分割の各検証用データに対する RMSE

\begin{tabular}{|c|r|r|r|r|}
\hline \multirow{2}{*}{ モデル } & \multicolumn{4}{|c|}{ 検証用データの路線 } \\
\cline { 2 - 5 } & \multicolumn{1}{|c|}{ 高松 } & \multicolumn{1}{|c|}{ 松山 } & \multicolumn{1}{c|}{ 高知 } & \multicolumn{1}{c|}{ 徳島 } \\
\hline 重回帰 & 2.83 & 3.56 & 4.89 & 5.00 \\
\hline DL & 3.34 & 5.22 & 7.67 & 5.57 \\
\hline
\end{tabular}

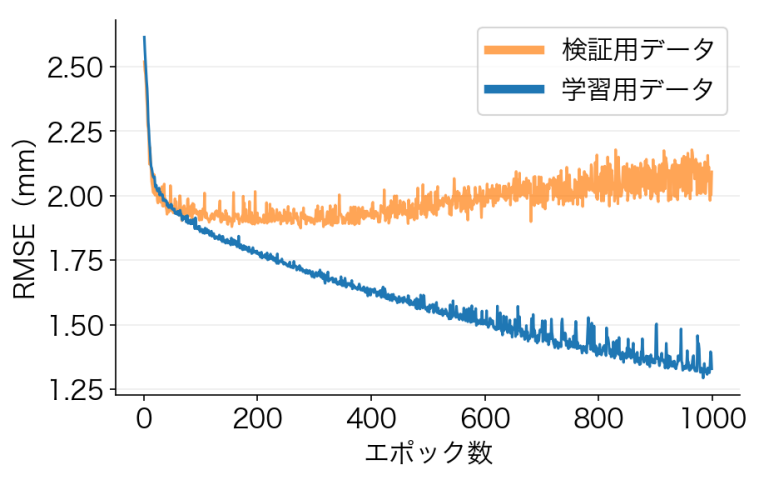

図-3 学習エポック数に伴う予測再現性の推移

DLモデルより優れた值を示した. また, 両モデルとも, ランダム分割検証結果と比較するとRMSEが大きく上昇 しており, 空間移転性を有していないことが示された.

\section{(2) 考察}

路線別分割検証によって，両モデル共に空間移転性 を有しないとの結果が得られた. この検証における, 各 検証用データに対する予測再現性（表-6）を確認すると,

「大型車交通量が少ない」，「カーブ・トンネル・コン クリート舗装の区間が多い」，「降水量が多い」，さら には「わだち掘れが深い」といった他路線とは異なる特 徵を有する高知自動車道のデータを検証用データとした ケースにおいて特に再現性が低下している.すなおち, 教師データに使用した他の3路線との類似性が低い路線 を検証用データに用いたことで再現性が低下したものと 推察される. また, 路面性状值に関して, 本研究による データは, 同一路線内で最新の調査結果のみを用いてい るが，異なる路線間では調査時期が異なるため, 測定誤 差の影響を路線間では排除しきれなかった可能性もある と考えられる.

さらに，DLモデルは，ランダム分割による検証では 重回帰モデルよりも再現性が高かったのに対し，路線別 分割による検証では，重回帰モデルよりも低い再現性し か得られなかったことから，DLモデルが過学習を行っ 
た可能性が考えられる，そこで，過学習の有無を検証す るため, DLモデルのエポック数に伴うRMSEの推移を確 認した（図-3）。学習用データに対する再現性はエポッ クを重ねる毎に高くなっているが，検証用データに対す る再現性は，エポック数が200に近づいたあたりから学 習を重ねるにつれて徐々に低くなっており，やはり過学 習が起きていることが示された.

\section{7. 結論}

本研究では, 四国の高速道路を対象として, ディープ ラーニングによる路面劣化予測モデルを構築し, 従来手 法である重回帰モデルと比較することで，その予測再現 性を定量的に検証した. 測定誤差の影響を排除するため, モデルの目的変数には最新の路面性状調査值のみを使用 した.

まず，隠れ層の数・隠れ層のユニット数・活性化関数 の種類を変更した複数のネットワークを構築し，K分割 交差検証を用いて検証用データに対するRMSEを算出し, 予測再現性の高いネットワーク構造の検証を行った．そ の結果, 隠れ層の数が4層・ユニット数が全て $100 ・$ 活性 化関数が全てReLU関数の構造を最適と判断した.

次に，DLモデルの有用性を検証するため，従来手法 である重回帰モデルとの予測再現性の比較を行った．そ の結果，重回帰モデルより高い再現性を有していること が示された. さらに，路線別にデータを分割して検証を 行うことで，モデルの空間移転性を確認した結果，DL モデル・重回帰モデル共に空間移転性を有していないと いう結果が得られた．また，DLモデルがより低い再現 性を示したため, エポック数に伴う再現性の推移を確認 したところ，その原因の1つとして過学習が挙げられる ことが示された.

先行研究では, 調査機器や施工方法などの要因・条件 を説明変数に用いているものや，過学習を抑える手法で あるドロップアウトを採用したネットワークを用いてモ
デルを構築しているものがある. これらによって, より 高い再現性や, 空間移転性を備えたモデルの構築を目指 すことが考えられる．また，比較対象の手法については， 本研究で使用した重回帰モデルに留まらず, 他の提案手 法との比較を通じた提案モデルの検証が必要であるが, これらは今後の課題としたい.

\section{参考文献}

1) 阿部頼政, 飯野忠雄: わだち掘れ測定データの解析 法に関する研究, 土木学会論文集, No. 478/V-21, pp. 117-123, 1993.

2) 重原大二朗, 西澤辰男, 中源達雄, 平野誠志 : ニュ ーラルネットワークによる北陸地方のアスファルト 舗装わだち掘れ進行モデル, 土木学会舗装工学論文 集, Vol. 13, pp. 25-30, 2008.

3) 奥田知之, 黒須秀明, 神武直彦 : 舖装維持管理効率 化のためのニューラルネットを用いた路面性状値予 測の検討, 情報処理学会第 78 回全国大会講演論文集, pp. 45-46, 2016.

4) 奥田知之, 鈴木康豊, 神武直彦: 将来予測精度を考 慮した舗装劣化予測モデルの精度評価手法の提案と 検証, 土木学会論文集 E1 (舗装工学), Vol. 73, No. 3, pp. I_229-I_236, 2017.

5) 大窪和明, 全邦釘, 橋爪謙治, 藤田尚 : 道路舗装の 劣化速度に関する探索的空間データ分析, 土木学会 論文集 E1 (舗装工学)，Vol. 74, No. 3, pp. 95-103, 2018.

6) Gong, H., Sun, Y., Mei, Z. and Huang, B.: Improving accuracy of rutting prediction for mechanistic-empirical pavement design guide with deep neural networks, Construction and Building Materials, Vol. 190, pp. 710-718, 2018.

7) Hoegh, K., Khazanovich, L. and Jense, M. : Local calibration of Mechanistic-Empirical pavement design guide rutting model: Minnesota road research project test sections, Transportation Research Record: Journal of Transportation Research Board, Vol. 2180, pp. 130-141, 2010.

8) 岡谷貴之: 機械学習プロフェッショナルシリーズ 深 層学習, 講談社, 2015.

(Received June 21, 2019) (Accepted January 14, 2020) 


\section{A PAVEMENT DETERIORATION FORECASTING MODEL IN EXPRESSWAYS USING DEEP LEARNING}

\section{Shin HASHIMOTO, Toshio YOSHII, Takahiro TSUBOTA and Pang-jo CHUN}

This study develops a deep learning model for forecasting pavement deterioration in an expressway. Road pavement plays an important role for road traffic by providing comfortable and safe driving environment. It is therefore crucial to forecast its deterioration, based on which timely and strategical maintenance can be implemented. Much literature has been reported on predicting pavement deterioration based on statistical modeling approached by utilizing pavement surface condition data. However, few studies have been conducted based on the deep learning approaches, which could be suitable in modeling the nonlinear process of the pavement deterioration. This study employs the multilayer perception network for developing the pavement deterioration forecasting model in an expressway network of Shikoku, Japan. The proposed model is then compared with a benchmark model which is based on the multivariable regression model. The comparison by the RMSE has identified that the proposed model is superior in forecasting the pavement deterioration. It has also been revealed that the model has limited capability in migrating to different road networks due to the overfitting. 